\title{
Unravelling the conundrum of entrepreneurial intentions, entrepreneurship education, and entrepreneurial characteristics
}

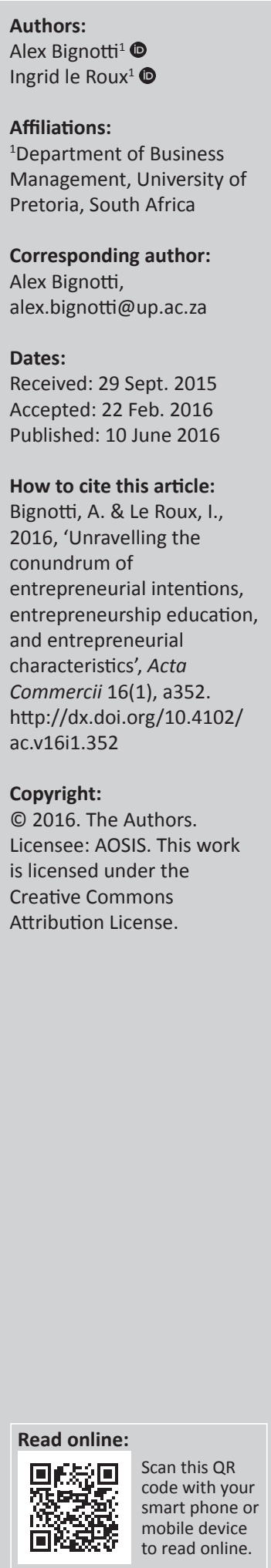

Orientation: Against the backdrop of recent youth unemployment dynamics, scholars have increasingly focused their attention on youth entrepreneurial intentions and their associated factors, such as entrepreneurship education and entrepreneurial characteristics.

Research purpose: This article investigated the individual and combined effect of entrepreneurship education and entrepreneurial characteristics on youth entrepreneurial intentions.

Motivation for the study: Notwithstanding the popularity of entrepreneurship education, its impact on learners' entrepreneurial intentions is still not clearly established in the literature. Moreover, whilst there is a growing consensus about the influence of certain entrepreneurial characteristics on entrepreneurial intentions, rarely has the role of entrepreneurship education in this relationship been examined.

Research design, approach and method: Data for the analysis came from a cross-sectional survey of secondary students enrolled in Junior Achievement South Africa (JASA)'s Mini Enterprise Programme and a control group of secondary students. The data-collection instrument was a questionnaire compiled from previously validated statements, which was validly completed by 827 respondents.

Main findings: Hierarchical logistic regression analysis revealed that entrepreneurship education and entrepreneurial characteristics per se do not influence entrepreneurial intentions positively. However, once interaction effects were introduced, entrepreneurship education moderated the influence of need for achievement and family support on entrepreneurial intentions in a positive direction.

Practical/managerial implications: Entrepreneurship-education-and-training institutions such as JASA should selectively screen their candidates to ensure that they also possess need for achievement and support from their close family.

Contribution/value add: This is the first study investigating both the individual and combined effect of entrepreneurship education and entrepreneurial characteristics on secondary students' entrepreneurial intentions.

\section{Introduction}

Entrepreneurial intentions (EI) have consistently represented a relevant construct in entrepreneurship research, based on the evidence that they predict future entrepreneurial activity, even in the very long term (Liñán \& Fayolle 2015:922). Furthermore, an increasing number of studies (e.g., Paço et al. 2011; Sánchez 2013; Støren 2014; Zhang, Duysters \& Cloodt 2014) have recently also focused on youth EI. The attention paid to youth EI is congruent with entrepreneurship being regarded as a possible alternative to formal employment, given that the labour force is not accommodating all the young graduates that are seeking employment every year (Scarpetta, Sonnet \& Manfredi 2010:9).

Youth unemployment represents a worldwide problem. Youth is a stage during which people's dreams and life aspirations begin to take shape and influence future life choices. In this respect, it is crucial that young people participate meaningfully in the economy, or else they stand to be victims of what the International Labour Organisation (ILO) calls a long-run 'scarring effect' (Matsumoto, Hengge \& Islam 2012:1), whereby, once unemployed, it is even more difficult to find employment in the future. In this regard, the global youth unemployment rate of $13 \%$ for the period 2012 to 2014, coupled with steadily declining global youth labour force participation 
rates (ILO 2015), is a cause for concern. However, from the point of view of fostering youth EI, with its potential to curb the negative wave of youth unemployment, some research gaps exist.

A number of variables have been studied that may positively influence the development of EI. One of these catalytic variables is entrepreneurship education (EE), as there is evidence that people enrolled in EE programmes have significantly higher levels of EI (Fayolle \& Liñán 2014:664). Nonetheless, most studies fail to evaluate the efficacy of EE programmes (Fayolle 2013; Rideout \& Gray 2013), and there is still lack of consensus about the actual relationship between EE and EI (Marques et al. 2012:662).

Moreover, whilst the study of entrepreneurial characteristics (EC) had been abandoned because these variables have not explained entrepreneurial behaviour exhaustively, this research area has re-emerged based on evidence that EC are associated with entrepreneurship (Gürol \& Atsan 2006; Kalkan \& Kaygusuz 2012). However, there appear to be no studies combining these socio-cognitive and psychocognitive dimensions of education with $\mathrm{EE}$ to consider their joint impact on EI, despite claims that people's EC represent an important dimension when devising adequate entrepreneurship educational programmes (Martínez et al. 2010:14). The closest instance is Ertuna and Gurel's (2011) study, which examined the moderating role of higher education on the relationship between university students' personality traits and EI.

Finally, very few studies have focused on the EI of specific sub-samples, such as secondary students (Liñán \& Fayolle 2015:918). Secondary students in particular represent a relevant youth sub-sample, as adolescence is a crucial life stage when career interests tend to stabilise and positive attitudes toward entrepreneurship as a career are formed (Fatoki \& Chindoga 2012:309).

Based on the above discussion, a few research questions emerge. Does EE contribute to developing secondary students' EI? Do secondary students' EC influence their EI? What is the combined effect between EE and EC on secondary students' EI?

This article seeks to answer the above research questions with respect to a specific EE programme for secondary students in South Africa: the Mini Enterprise Programme run by Junior Achievement South Africa (JASA). JASA is one of the most active EE institutions in South Africa targeting secondary students. This article evaluates the efficacy of the programme in question by assessing whether enrolment in the programme influences EI. It also examines the relationship between a set of EC and learners' EI. Finally, it analyses the moderating effect of EE on the relationship between the EC investigated and EI.

Consequently, this article seeks to contribute to EI research in several ways. Firstly, it performs an efficacy evaluation of a specific EE programme, in terms of its ability to develop learners' EI. Secondly, it investigates both the individual and combined effect of EE and EC on youth EI. Finally, it surveys youth EI amongst secondary students. Altogether, this article makes a novel contribution, in that it is the first study exploring the nomological network, or network of relationships, between EI, EE and EC in a secondary-student population.

With these goals in mind, the article is structured as follows. Initially, extant literature on EI, EE and EC is reviewed. Then, JASA and its Mini Enterprise Programme are outlined. Subsequently, the research method and design are described. After results are presented and then discussed, the article ends with conclusions, limitations and recommendations.

\section{Literature review Youth entrepreneurial intentions}

Intentions-based models of entrepreneurship have been used extensively to study entrepreneurial behaviour. Initiated by scholars such as Ajzen (1991) and Shapero and Sokol (1982), the body of research on EI is substantial, anchored on the evidence that intentions predict behaviour accurately (Ajzen 2011:1114).

EI have aroused the interest of scholars studying how to promote youth entrepreneurial activity. In the light of the current youth unemployment dilemma and the widespread belief in entrepreneurship as a way of out of unemployment (Fatoki \& Chindoga 2012:308), researchers have observed that people already form career interests during adolescence (Marques et al. 2012:658), one career option being that of starting and running one's own business. This observation renders secondary students a relevant population in the youth EI research stream. The focus on youth EI at secondary level is in line with the promotion of entrepreneurial behaviour at the level of intentions, considering that it is unlikely to expect secondary students to start a business during their school years or shortly after school, as they perceive that they lack capital, skills, support, and market opportunities, and this applies especially to youth in subSaharan Africa (Kew et al. 2013:13).

A number of recent studies have, more specifically, investigated secondary students' $\mathrm{EI}$ and associated factors. This testifies to the fact that, whilst many scholars have examined the EI of university students, the interest in secondary students' EI is growing. The focus of these studies has consistently been the factors fostering youth EI.

The catalytic role of EE for the development of secondary students' EI has been analysed, but with mixed results. Athayde (2009) and Steenekamp, Van der Merwe and Athayde (2011) found that the EE programmes they studied were associated with higher levels of secondary students' EI. Sánchez (2013), basing himself on the Theory of Planned Behaviour (TPB), reported that the EE programme in question raised secondary students' EI levels. On the contrary, Marques 
et al. (2012) and Rodrigues et al. (2012), also using the TPB as a theoretical foundation, found no statistically significant relationship between EE and secondary students' EI.

Another set of antecedent factors of EI, investigated in secondary-student samples, is represented by EC. For instance, Ferreira et al. (2012) observed that need for achievement, self-confidence and personal attitude toward entrepreneurship impact positively on secondary students' EI. Likewise, Marques et al. (2012) obtained the same results for need for achievement and personal attitude, and Sánchez (2013) for self-efficacy, pro-activeness, and risk taking. Dinis et al. (2013) observed a positive influence of self-confidence and need for achievement on secondary students' EI, but a negative impact of propensity to risk. Following a contextual focus, Athayde (2009) found that ethnic background and family entrepreneurial background have a positive influence on secondary students' EI. In Mahadea, Ramroop and Zewotir's (2011) study, secondary students' interest in starting a business in the future was influenced by gender, ethnic background, role models and acquired skills.

It is worth noting that all the mentioned studies focusing on secondary students' EI have examined the role of either EE or EC in the development of youth EI. The next section covers literature on these two constructs.

\section{Entrepreneurship education}

EE is booming as an academic and practice field (Neck \& Greene 2011), owing to the scholarly consensus that entrepreneurship can be taught (Mwasalwiba 2010:40). The number of EE courses has progressively risen, both at postsecondary level (Rideout \& Gray 2013:330), and at primary and secondary-school level (Fayolle 2013:692). As a field of research, EE is vast and lacks uniformity (Henry, Hill \& Leitch 2005:165). This has given rise to a plethora of different EE programmes, rendering this discipline highly fragmented and not cumulative in its practice and research trends (Fayolle 2013:697). Although some common areas of investigation have developed (Béchard \& Grégoire 2005), what emerges is the lack of research assessing the impact of EE interventions (Henry et al. 2005:165). As is the case for any field of research that has practical implications, there is a need to reflect on the effectiveness of EE practices (Fayolle 2013:693). Additionally, there have been calls to examine causal links between EE variables and EE impact measures (Fayolle \& Liñán 2014:664).

From a theoretical point of view, scholars have often used intentions-based models to assess the impact of EE interventions (Raposo \& Paço 2011:456). More specifically, EI have been used as a measure of EE effectiveness, as intentions have proved to predict behaviour accurately (Krueger, Reilly \& Carsrud 2000:416). Recent studies establishing a causal relationship between EE variables and EI have yielded promising results (Støren 2014; Zhang et al. 2014), revealing that EI levels are higher for people who participate in an EE programme. It may be argued that EI represent an appropriate measure of EE programme effectiveness for secondary-school participants, as it can hardly be expected of young people at secondary-school level to have gathered the resources and acquired the skills needed to start a business.

Notwithstanding the considerable number of studies investigating the relationship between EE and EI, there is still lack of consensus on the actual relationship between these two variables (Marques et al. 2012:662), especially with regards to secondary students, as the mixed results reported earlier on reveal.

One of the objectives of this article is to assess the effectiveness of a specific EE programme for secondary students, thus investigating the positive impact of $\mathrm{EE}$ on secondary students' EI. From this objective and the above discussion, the following first hypothesis can be formulated:

$\mathbf{H}_{\mathbf{1}}$ : EE influences secondary students' EI positively.

The next section covers extant literature on EC and addresses the interplay between EI, EE and EC.

\section{Entrepreneurial characteristics}

A great part of research on EC is conducted according to the behaviourist view of entrepreneurship, and is based on or associated with intentions-based models. Recent studies have in fact found that personal characteristics and elements are related to EI (Zhao, Seibert \& Lumpkin 2010), and have advocated not to abandon the investigation of personal elements in entrepreneurship research. These personal-level variables may be understood as the psychological variables that set entrepreneurs apart from non-entrepreneurs (Koh 1996:13). There is also consensus that contextual variables such as family background and role models play a role in the formation of EI, although they are not direct predictors (Turker \& Sonmez Selcuk 2009). Altogether, these personallevel and contextual variables may be termed 'entrepreneurial characteristics' (Gürol \& Atsan 2006:28; Sánchez 2013:449).

A number of authors have attempted to outline the most relevant EC for the emergence of entrepreneurial behaviour, and there seems to be consensus about which EC are more prominent (Kalkan \& Kaygusuz 2012:4; Marques et al. 2012:660; Oosterbeek, Van Praag \& Ijsselstein 2010:446; Rauch \& Frese 2007). Whilst a comprehensive review of the EC reported in previous studies is beyond the scope of this article, the following six constructs represent some of the most commonly reported EC:

- Need for achievement.

- Locus of control.

- Tolerance of ambiguity.

- Role models.

- Family support.

- Community support.

Literature in support of these six EC is addressed next.

Need for achievement is a widely researched EC, and is a personal trait that is exhibited by individuals who seek 
challenging tasks, accept responsibility for them and demand feedback on their execution (Rauch \& Frese 2007:358). Some studies indicate that this variable is related to EI (Rauch \& Frese 2007; Zeffane 2013). There is evidence that locus of control, understood as internal control and defined as people's attribution of the reasons for an occurrence to themselves, is also a personal factor associated with entrepreneurship (Kroeck, Bullough \& Reynolds 2010). Other studies have concluded that tolerance of ambiguity may also represent an important EC (Ferreira et al. 2012). This construct corresponds to people's propensity to view challenging situations positively where sufficient information is lacking (Koh 1996:15).

Contextual variables may also be related to people's EI. Social factors such as family support, community support and role models have been found extensively to be associated with these intentions (BarNir, Watson \& Hutchins 2011; Davidsson \& Honig 2003; Quan 2012). Family support is a social factor that entails the support people receive from their family for engaging in entrepreneurial behaviour (Chang et al. 2009:284). Community support, often equated with social networks, is the support the community gives to individuals' EI by providing valuable resources such as information, advice and even finance (Tas, Citci \& Cesteneci 2012). Role models, who are often represented by people in one's close circle of relatives and acquaintances, may fulfil the following functions: teach by example, teach by actual support, foster entrepreneurial self-efficacy and give inspiration and motivation (Bosma et al. 2012:422). Chlosta et al. (2010:132) found that having parental role models increases the likelihood of being self-employed in the future.

Given that EC are re-emerging in entrepreneurship research, and taking into account the scarcity of studies following this re-emerging trend, the following hypothesis is also formulated, and will be tested for each EC investigated in this article:

\section{$\mathbf{H}_{2}:$ EC positively influence secondary students' EI.}

In EI research there is scarcity of studies exploring the nomological network between EI, EE and EC, especially using secondary-student samples. The present literature review reveals how some scholars have focused on investigating the relationship between EE and secondary students' EI, whilst others have addressed the impact of EC on their EI. A few studies (Athayde 2009; Marques et al. 2012; Rodrigues et al. 2012; Sánchez 2013) consider simultaneously the relationship between EE and EI, and between EC and EI, but fail to investigate the combined effect of EE and EC on EI. Ertuna and Gurel's (2011) study of the moderating effect of higher education on the influence of personality traits on university students' EI represents one of the closest attempts at completing this network of relationships, although the sample used was not represented by secondary students.

Thus, the following final hypothesis can be formulated, with the objective of exploring a possible extension of the network of relationships between EI, EE and EC and its analysis in a secondary-student sample:
$\mathbf{H}_{3}$ : EE has a moderating effect on the relationship between secondary students' EC and EI.

In order to test the above hypotheses in a concrete EE context, this article examines a specific EE programme targeting secondary students, namely JASA's Mini Enterprise Programme. Other studies have followed a similarly focused approach, and have analysed comparable EE programmes targeted at young people, such as Young Achievement Australia's enterprise programme (Peterman \& Kennedy 2003) and Junior Achievement-Young Enterprise's Student Mini Company Programme (Oosterbeek et al. 2010).

The following section introduces JASA and its Mini Enterprise Programme, which is the specific EE programme examined in this article.

\section{Junior Achievement South Africa}

JASA is an entrepreneurship-education-and-training institution that has operated in South Africa since 1979 (Collett \& Gale 2012:5). In an interview on 25 November 2014, Ms L. McClure, JASA's managing director, explained that JASA's entrepreneurship programmes target grade 10 and 11 secondary-school learners and aim to equip them with the necessary skills to start their own business. JASA also runs programmes for primary school learners and for out of school unemployed youth.

Once its funding organisations request JASA to cover a certain geographical area, JASA scouts and evaluates the secondary schools where to run its programmes. Ms L. McClure stated in the same interview that the decision to approach a school is based on the size of the school, how many learners are in grade 10 and 11, and whether there are other entrepreneurship programmes already run at the school, or any other activities that could impact on the ability of the learners to commit the time required for JASA's programme. As the secondary-school learners that represent the treatment group of this article participated in JASA's Mini Enterprise Programme, the remainder of this section gives an outline of this programme.

The Mini Enterprise Programme is a three-month entrepreneurship programme that aims to develop a theoretical understanding of business start-up and management and to engage learners in the practical aspects of entrepreneurship. It makes use of both classroom teaching and hands-on activities (Junior Achievement South Africa n.d.). As elucidated by Ms L. McClure, JASA advertises the programme to grade 10 and 11 learners of partner schools, and students who wish to participate in the programme enrol for it. As the maximum number of programme participants taken on by JASA is 45 learners JASA has to carry out a selection of candidates when applications exceed this number. Once the programme participants have been finalised, the class is split into two groups, which represent two separate enterprises. 
Over the course of 12 weeks, learners meet once a week for three hours. During the first three weeks, they learn the basics of business management, including general management, pricing, financial planning, stock control, sales and marketing, and company shares. During the fourth week, the two enterprises - represented by the two learner groups - are established, and each enterprise nominates and elects its managers (Junior Achievement South Africa n.d.). Ms L. McClure further illustrated that managers are required to purchase four shares at ZAR5.00 each. Over the course of the next seven weeks, the learners run their enterprise, and are exposed to hands-on activities. They develop their product, decide on its pricing, and sell it within their community. Salespeople receive a commission on their sales. JASA gives each enterprise up to ZAR1200.00 credit, which learners may utilise to purchase supplies on credit from JASA. Learners also keep a record of their cash transactions, and deposit the revenue collected from sales into the enterprise's bank account; in this way they learn some basics of cash flow and how to operate a bank account. During the 12th and last week, the enterprise is liquidated, and learners see their enterprise's three-month bank statement. All those who bought shares receive dividends (if this is what the mini-business decides upon), and all the learners receive their salary and keep what is left over of the profits once the above remunerations are paid out.

\section{Research method and design}

Starting from the theoretical and methodological gaps identified above, this article seeks to contribute to entrepreneurship research under the following respects:

- Assessing the effectiveness of a specific EE programme by analysing the impact of enrolment in JASA's Mini Enterprise Programme on secondary students' EI, thus examining the effect of EE on youth EI.

- Investigating the influence of EC on youth EI.

- Exploring the moderating effect of EE on the relationship between the EC investigated and youth EI.

- Using secondary students as sampling frame.

This article follows a post-test-only, group comparison design. It treats EE and a set of EC as independent variables, and $\mathrm{EI}$ as the dependent variable; $\mathrm{EE}$ is treated also as a moderator. The groups of comparison are represented by secondary students enrolled in JASA's Mini Enterprise Programme and secondary students not enrolled in any entrepreneurship programme.

\section{Sample}

Secondary students at South African schools, enrolled in grade 10, 11 and 12, represented the target population. The secondary schools included in this investigation were 18 schools, both urban and rural, located in the South African provinces of Gauteng and Limpopo. For the decision on which schools should be included in the investigation, convenience sampling was used: the schools were easily accessible by the researcher or were part of JASA's network of partner schools.
The sample represented by secondary-school learners that participated in JASA's Mini Enterprise Programme (JASA group) was composed of 404 learners, enrolled in grade 10 and 11. The control group sample, represented by grade 10, 11 and 12 secondary students, numbered 423 learners. For both sample groups, random sampling was used: each learner had an equal and known chance of being selected.

\section{Instrument}

Respondents were administered a questionnaire comprising statements measuring EI, the EC investigated in this article, and demographic variables. Some statements were modified in order to make them more comprehensible and appropriate to secondary students.

EI were determined by the following statement, 'I consider running my own business as an employment option for me after school/university', derived from similar statements used by other researchers (Krueger 1993:11; Urban 2006:95), where respondents were asked to state their EI on a dichotomous 'yes-no' scale.

The EC need for achievement, locus of control, tolerance of ambiguity, role models, family support, and community support were measured by the questionnaire on a five-point Likert scale. Need for achievement was measured by five items, taken from Steers and Braunstein's (1976:254) Measure of Manifest Needs. Locus of control was measured by 11 items, selected from Louden (1978:293) and converted from questions to statements. Tolerance of ambiguity was measured by 12 items, as formulated by Herman et al. (2010:64). Role models were determined by 12 items, selected from Nauta and Kokaly (2001:91). Family support was measured by seven items, taken from Carr and Sequeira's (2007:1097) Measure of Perceived Family Support. Community support was measured by 10 items, sourced from Liao and Welsch (2005:354). Finally, EE was measured by indicating to which sample group - JASA or the control group - the respondent belonged.

\section{Statistical analyses}

An exploratory factor analysis, using maximum likelihood estimation with direct quartimin rotation, was conducted to verify the construct validity of the sets of items measuring the constructs locus of control, tolerance of ambiguity, community support and role models. These items were rated on a five-point Likert scale measuring agreement (where $1=$ 'strongly disagree' and $5=$ 'strongly agree').

The questionnaire included statements for the constructs need for achievement and family support separately, as these items were rated on a five-point Likert response scale that measured frequency for need for achievement (where $1=$ 'never' and $5=$ 'always') and quality for family support (where 1 = 'extremely negative' and 5 = 'extremely positive'), as opposed to measuring agreement as in the case of the other constructs. An exploratory factor analysis using 
principal component extraction and varimax rotation was run on each of these two constructs to verify their unidimensionality. Need for achievement and family support were also item-analysed to verify their internal consistency (reliability).

To test the hypotheses, a hierarchical logistical regression approach was followed, with EI as dependent variable. Because the dependent variable EI is dichotomous, binary logistic regression is the most suitable regression analysis to test this construct's directional relationship with the independent variables EE and EC (Peng, Lee \& Ingersoll 2002:3). Two different logistic regression models were run. The first model entered enrolment in JASA's Mini Enterprise Programme (as a proxy for EE) and the EC investigated to determine if they have a positive directional relationship with EI $\left(\mathrm{H}_{1}\right.$ and $\left.\mathrm{H}_{2}\right)$. The second model further introduced the interaction-effect of EE on each of the EC investigated, and tested whether EE behaves as a moderator $\left(\mathrm{H}_{3}\right)$ by observing any changes in the strength and/or direction of the relationship between the EC investigated and EI.

\section{Results}

The factor analysis for locus of control, tolerance of ambiguity, family support and community support suggested the existence of four factors: locus of control, role models (guidance), role models (inspirational figure) and community support. The 'best fit' factor analysis accounts for 30\% of the variance. Table 1 summarises the results of this and the subsequent two factor analyses.

As it appears from Table 1, the factor analysis could not identify tolerance of ambiguity as a factor. Furthermore, Table 1 shows that respondents distinguished between having role models that give them guidance and support in their career and life decisions, and role models that inspire them in their career pursuits. These two sub-constructs are referred to as 'role models (guidance)' and 'role models (inspirational figure)' in the rest of the article.

Factor analyses 2 and 3 were run to determine if need for achievement and family support each represented a single construct. The Kaiser-Meyer-Olkin Measure of Sampling Adequacy (0.641 for need for achievement and 0.806 for family support) and the Bartlett's Test of Sphericity being significant $(p=0.000)$ both indicated that a factor analysis was appropriate. With regards to need for achievement, the factor analysis confirmed the existence of a single construct. As for family support, the factor analysis revealed the existence of two constructs, after rotating the factor loadings using the Oblimin with Kaiser Method (final factor loadings are reported in Table 1). The original family support construct turned out to represent two sub-constructs, namely, support from members of one's close family and support from other people, such as friends, neighbours and acquaintances. These two sub-constructs are referred to as 'support (family)' and 'support (others)' in the rest of the article.

Overall, seven EC emerged as constructs from the factor analyses. Their descriptive statistics and correlations are summarised in Table 2. These seven EC represent, together with EE (enrolment in JASA's Mini Enterprise Programme), the final set of independent variables.

Coming to hypothesis testing, an initial cross-tabulation of the 'yes-no' values for EI for the JASA and control group revealed that $82.9 \%$ of JASA respondents, who are exposed to an EE intervention, had EI (said 'yes' for intending to start a business), whilst a lower percentage (74.7\%) of control group respondents had the same intentions. The chi-square test of independence confirmed the statistical significance of these results $\left(\chi^{2}[1]=8.327 ; p=0.004\right)$. Thus there appears to be an association between $\mathrm{EE}$ and $\mathrm{EI}$.

The positive directional relationship between the independent variables EE and EC and the dependent variable EI, and the moderating effect of EE on the EC-EI relationship, were tested using hierarchical logistic regression. Table 3 provides an overview of the hierarchical logistic regression results. Model 1 introduced EE and the seven EC investigated as predictors. The Hosmer and Lemeshow goodness-of-fit test and the model's chi-square statistic demonstrated that the null hypothesis of the logistic model including enrolment in EE (JASA's programme) and the EC as predictors of EI cannot be rejected, and thus indicated a fit. As shown in Table 3, only support (family) and community support were highly statistically significant predictors $(p<0.05)$ in Model 1 , but in a negative direction: increasing the level of support (family) and community support by one unit will make it roughly twice $(1 / 0.486)$ and one-and-a-half times (1/0.633) less likely, respectively, for students to have EI. Neither $\mathrm{H}_{1}$ nor $\mathrm{H}_{2}$ was supported.

TABLE 1: Summary results of factor analyses.

\begin{tabular}{|c|c|c|c|c|c|}
\hline Factor & Number of items in factor & Eigenvalue & $\begin{array}{c}\text { Variance explained by factor } \\
(\%)\end{array}$ & $\begin{array}{c}\text { Cumul. variance explained } \\
(\%)\end{array}$ & Cronbach's alpha reliability \\
\hline \multicolumn{6}{|l|}{ Factor Analysis 1} \\
\hline Role models (guidance) & 6 & 4.12 & 14.41 & 14.41 & 0.76 \\
\hline Community support & 8 & 2.5 & 7.47 & 21.88 & 0.71 \\
\hline Role models (inspirational figure) & 4 & 1.68 & 4.34 & 26.22 & 0.66 \\
\hline Locus of control & 6 & 1.57 & 4.08 & 30.30 & 0.54 \\
\hline \multicolumn{6}{|l|}{ Factor Analysis 2} \\
\hline Need for achievement & 3 & 1.69 & 56.20 & 56.20 & 0.6 \\
\hline \multicolumn{6}{|l|}{ Factor Analysis 3} \\
\hline Support (others) & 4 & 2.93 & 41.90 & 41.90 & 0.66 \\
\hline Support (family) & 3 & 1.02 & 14.50 & 56.40 & 0.69 \\
\hline
\end{tabular}

Source: Authors' own work 
TABLE 2: Descriptive statistics and correlations of factors.

\begin{tabular}{|c|c|c|c|c|c|c|c|c|c|}
\hline Variable & Mean & SD & 1 & 2 & 3 & 4 & 5 & 6 & 7 \\
\hline 1. Need for achievement & 4.27 & 0.64 & 1 & - & - & - & - & - & - \\
\hline 2. Locus of control & 3.37 & 0.68 & $0.12 *$ & 1 & - & - & - & - & - \\
\hline 3. Role models (guidance) & 3.92 & 0.73 & $0.23 *$ & $0.20 *$ & 1 & - & - & - & - \\
\hline 4. Role models: inspirational figure & 3.36 & 0.89 & $0.22 *$ & $0.08 * *$ & $0.30 *$ & 1 & - & - & - \\
\hline 5. Support (family) & 3.95 & 0.7 & $0.24 *$ & 0.05 & $0.38 *$ & $0.24 *$ & 1 & - & - \\
\hline 6. Support (others) & 3.53 & 0.62 & $0.14 *$ & $0.09 * *$ & $0.22 *$ & $0.10 *$ & $0.51 *$ & 1 & - \\
\hline 7. Community support & 3.84 & 0.56 & $0.40 *$ & $-0.06 * * *$ & $0.27 *$ & $0.23 *$ & $0.36 *$ & $0.25 *$ & 1 \\
\hline
\end{tabular}

Source: Authors' own compilation

$\mathrm{SD}$, standard deviation.

$*, p<0.01 ; * *, p<0.05 ; * * *, p<0.10$

TABLE 3: Logistic regression analysis results for entrepreneurial intentions.

\begin{tabular}{|c|c|c|c|c|c|c|c|c|}
\hline \multirow[t]{2}{*}{ Variables } & \multicolumn{4}{|c|}{ Model 1} & \multicolumn{4}{|c|}{ Model 2} \\
\hline & $\beta$ & S.E. $\beta$ & $p$ & $\operatorname{Exp}(\beta)$ & $\beta$ & S.E $\beta$ & $p$ & $\operatorname{Exp}(\beta)$ \\
\hline Constant & 2.188 & 0.904 & 0.016 & 8.913 & 3.696 & 3.111 & 0.235 & 40.268 \\
\hline $\mathrm{EE}$ & -0.052 & 0.231 & 0.821 & 0.949 & -0.058 & 0.261 & 0.824 & 0.943 \\
\hline Need for achievement & 0.196 & 0.164 & 0.233 & 1.216 & -0.966 & 0.518 & 0.062 & 0.381 \\
\hline Locus of control & 0.168 & 0.141 & 0.234 & 1.183 & 0.724 & 0.448 & 0.106 & 2.064 \\
\hline Role models (guidance) & 0.129 & 0.139 & 0.356 & 1.137 & 0.305 & 0.429 & 0.477 & 1.357 \\
\hline Role models (inspirational figure) & 0.03 & 0.109 & 0.78 & 1.031 & 0.583 & 0.336 & 0.082 & 1.792 \\
\hline Support (family) & -0.721 & 0.159 & 0.000 & 0.486 & -2.029 & 0.561 & 0.000 & 0.131 \\
\hline Support (other) & -0.266 & 0.176 & 0.13 & 0.766 & 0.283 & 0.645 & 0.66 & 1.328 \\
\hline Community support & -0.458 & 0.204 & 0.025 & 0.633 & 0.091 & 0.642 & 0.887 & 1.096 \\
\hline \multicolumn{9}{|l|}{ Interaction-effect of EE } \\
\hline Need for achievement & - & - & - & - & 0.571 & 0.251 & 0.023 & 1.77 \\
\hline Locus of control & - & - & - & - & -0.257 & 0.197 & 0.191 & 0.773 \\
\hline Role models (guidance) & - & - & - & - & -0.095 & 0.212 & 0.653 & 0.909 \\
\hline Support (family) & - & - & - & - & 0.594 & 0.242 & 0.014 & 1.812 \\
\hline Support (other) & - & - & - & - & -0.190 & 0.233 & 0.417 & 0.827 \\
\hline Community support & - & - & - & - & -0.217 & 0.232 & 0.35 & 0.805 \\
\hline Hosmer and Lemeshow Test & \multicolumn{2}{|c|}{$\chi^{2}(8)=0.540$} & \multicolumn{2}{|c|}{$p=1.000$} & \multicolumn{2}{|c|}{$\chi^{2}(8)=4.277$} & \multicolumn{2}{|c|}{$p=0.831$} \\
\hline-2 log likelihood & \multicolumn{2}{|c|}{779.098} & \multicolumn{2}{|c|}{-} & \multicolumn{2}{|c|}{763.911} & \multicolumn{2}{|c|}{-} \\
\hline Model chi-square & \multicolumn{2}{|c|}{61.614} & \multicolumn{2}{|c|}{$p=0.000$} & \multicolumn{2}{|c|}{76.802} & \multicolumn{2}{|c|}{$p=0.000$} \\
\hline Nagelkerke $R^{2}$ & \multicolumn{2}{|c|}{0.113} & \multicolumn{2}{|c|}{-} & \multicolumn{2}{|c|}{0.14} & \multicolumn{2}{|c|}{-} \\
\hline Percentage predicted correctly & \multicolumn{2}{|c|}{77.9} & \multicolumn{2}{|c|}{-} & \multicolumn{2}{|c|}{78.5} & \multicolumn{2}{|c|}{-} \\
\hline
\end{tabular}

Source: Authors' own work

$\mathrm{EE}$, entrepreneurship education.

Model 2 dealt with the analysis of whether EE acts as a moderator on the relationship between the EC investigated and EI. For this purpose, seven new variables were introduced in the logistic regression model. They each constitute the product of a standardised EC variable and EE. As interaction terms are often highly correlated with the terms from which they are created, standardised variables are used to decrease the correlation. These seven variables thus represent the interaction-effect of EE on each EC investigated. The new interaction-effect variables were entered in the logistic regression model as predictors of EI. A log likelihood ratio test between Model 1 and Model 2 revealed that Model 2 predicts EI more effectively $(D=15.188 ; d f=7 ; p<0.05)$. Accordingly, Model 2 had a higher Nagelkerke $R^{2}$ score, and correctly classified a higher percentage of cases.

Considering the moderating effect of EE on the EC investigated, the logistic regression analysis showed that, in Model 2, the interaction-effect of EE on need for achievement and the interaction-effect of EE on support (family) were statistically significant predictors at the $5 \%$ level. Increasing the interaction-effect of EE on need for achievement will result almost in a twofold increase in EI; the same applies to the interaction-effect of EE on support (family). If the results for need for achievement as a predictor of EI are taken into consideration (as they are statistically significant at the $10 \%$ level and close to the $5 \%$ level), what appears is that the moderating effect of EE changes the direction and strength of the impact of need for achievement on EI approximately from -3 (1/0.381) to +2 , and of the impact of support (family) roughly from -8 $(1 / 0.131)$ to +2 . Therefore, EE acts as a moderator of the relationship between the EC need for achievement and support (family) and EI, giving support to $\mathrm{H}_{3}$ for these two EC.

\section{Discussion}

An initial cross-tabulation of responses for EI between the JASA and control group revealed a relationship of association between EE and EI. However, the positive influence of EE on secondary students' EI was not confirmed by the hierarchical logistic regression results: Model 1 showed that EE does not 
have a statistically significant directional relationship with EI. In this article's concrete investigation, this means that enrolment in JASA's programme is not sufficient to positively influence learners' EI. This finding corroborates the results of other studies (Marques et al. 2012; Rodrigues et al. 2012) where the relationship between EE and secondary students' EI was statistically non-significant. It can be postulated that there are other concomitant variables responsible for the association between EE and EI.

The high percentage of learners exhibiting EI observed in the present article, both in the JASA and control group, is in striking opposition with the level of South African youth EI of $13 \%$ measured by Herrington, Kew and Kew (2015:44). It should, however, be kept in mind that these authors measured youth as people between 15 and 34 years of age, and that studies (Mahadea et al. 2011; Steenekamp et al. 2011:59) with secondary-school samples similar to the one used in this article also obtained high proportions of respondents with EI (58\% and above).

Concerning the hypothesised positive influence of EC on EI, the hierarchical logistic regression analysis revealed that students who exhibited support from their close family and support from the community at large are twice and one-anda-half times less likely, respectively, to have EI. It can be assumed that learners will leverage the support they find from their close family and within their community to find formal employment or a similar risk-averse career solution. Given that most youth entrepreneurship happens in the form of necessity entrepreneurship in South Africa (Kew et al. 2013:42), this finding is not surprising. Moreover, these results are analogous to those of other scholars surveying secondary students and investigating similar constructs, such as Marques et al. (2012), who observed a negative influence of family entrepreneurial background and subjective norm on EI. Similarly to what has been observed about EE above, these results indicate that EC are not sufficient for secondary students to develop EI.

Finally, the logistic regression analysis revealed that EE acts as a moderator of the relationship between the EC need for achievement and support (family) and EI. In particular, these results mean that need for achievement per se does not influence the development of EI. However, for students possessing need for achievement and enrolled in JASA's programme, it is expected that an increase in need for achievement will have a twofold positive effect on EI. It can be postulated that EE serves to trigger the positive effect of need for achievement on EI. As for support (family), this EC per se has a negative influence on EI, whilst for students enrolled in JASA's programme it has a twofold positive effect on EI. It thus appears that support from one's family counteracts the development of EI, unless coupled with EE, in which case EI are fostered.

\section{Conclusion}

Youth EI have attracted the interest of scholars and policymakers alike. Based on the evidence that EI predict entrepreneurial activity, research- and practice-based efforts to foster youth EI have multiplied, also founded on the awareness that entrepreneurship represents a possible solution to the youth unemployment dilemma. However, some gaps exist in youth EI research, which were identified in this article.

The first gap concerns EE, which has developed as a possible way to foster youth EI, in line with the growing consensus that entrepreneurship can be taught. Notwithstanding existing research on the ability of EE to develop learners' EI, however, to date the relationship between these two variables is still not clear. Especially in secondary-school settings, results have been mixed. Secondly, whilst there are studies examining the influence of EC on youth EI, rarely do scholars embrace the socio-cognitive, contextual and educational perspectives simultaneously, so that studies investigating the combined effect of EE and EC on youth EI are scarce and, in the case of secondary-student samples, non-existent. Finally, secondary students have been under-represented in the youth EI literature, although they represent a relevant population, given that career interests toward entrepreneurship may already form and eventually stabilise during adolescence.

This article addresses these research gaps by examining the relationship between participating in an EE programme for secondary students and respondents' EI. By so doing, it provides further evidence on the relationship between EE and youth EI. It incorporates a socio-cognitive and a contextual dimension in its investigation by also analysing the impact of a final set of seven EC on youth EI. A further contribution is the addition of a level of complexity by analysing the moderating effect of EE on the relationship between EC and EI. Finally, it is one of few studies surveying secondary students.

This article's main contribution lies in its being the first study exploring the nomological network between EI, EE and EC, using a secondary-student sample. The added degree of clarity over this network of relationships offered by this article can aid the development of more effective EE programmes.

The findings of this article reveal that neither participating in JASA's Mini Enterprise Programme, nor displaying a set of $\mathrm{EC}$, is sufficient to foster learners' EI. In the case of the EC investigated, there is even a negative influence on EI exerted by support from one's close family and support from the community at large. However, for students enrolled in JASA's programme, the influence of their need for achievement and the support they receive from their close family on EI becomes positive.

\section{Limitations and recommendations}

This article presents some methodological limitations. Firstly, although it employs a comparison between two groups, it is a post-test-only study. Testing students before and after the 
EE programme in question could have yielded more robust results. Secondly, its conclusions are based on logistic regression results, whose models have a low Nagelkerke $R^{2}$ index. The Nagelkerke $R^{2}$ value is an approximate indication of the variance in EI explained by predictors in the model. However, this index is only supplementary to other, more precise, evaluative indices such as the overall evaluation of the model and the goodness-of-fit test statistic (Peng et al. 2002:6). Although other goodness-of-fit indicators yielded better scores, the results of this article should be interpreted with caution.

From a theoretical perspective, including more EC or other variables in the analysis is also worth considering in future research, as the set of EC investigated in this article is not exhaustive. Further research is also needed to corroborate the results for the EC family support and community support, which behaved anomalously or in contrast with some previous research.

From a practice perspective, the results suggest that JASA's programme or EC in isolation are not sufficient to foster secondary students' EI. This article highlights how being enrolled in JASA's Mini Enterprise Programme, coupled with having need for achievement or support from one's close family, leads to a twofold increase in EI. Therefore, JASA should consider selectively screening their potential learners, as only those JASA learners with need for achievement or support from their close family are likely to exhibit higher EI. Recent studies based on secondary-student samples have also advocated for the consideration of learners' EC in EE programmes aimed at fostering youth EI (Dinis et al. 2013:775; Paço et al. 2011).

\section{Acknowledgements \\ Competing interests}

The authors declare that they have no financial or personal relationship(s) that may have inappropriately influenced them in writing this article.

\section{Authors' contributions}

A.B. contributed the background study and drove the datacollection phase of the study. I.L.R. collaborated with A.B. in formulating the research question, developing the research design, analysing the data, and interpreting the results of the study.

\section{References}

Ajzen, I., 1991, 'The theory of planned behavior', Organizational Behavior and Human Decision Processes 50(2), 179-211. http://dx.doi.org/10.1016/07495978(91)90020-T

Ajzen, I., 2011, 'The theory of planned behaviour: Reactions and reflections', Psychology and Health 26(9), 1113-1127. http://dx.doi.org/10.1080/08870446.2 011.613995

Athayde, R., 2009, 'Measuring enterprise potential in young people', Entrepreneurship Theory \& Practice 33(2), 481-500. http://dx.doi.org/10.1111/j.15406520.2009.00300.x

BarNir, A., Watson, W.E. \& Hutchins, H.M., 2011, 'Mediation and moderated mediation in the relationship among role models, self-efficacy, entrepreneurial career intention, and gender', Journal of Applied Social Psychology 41(2), 270-297. http://dx.doi.org/10.1111/j.1559-1816.2010.00713.x
Béchard, J.P. \& Grégoire, D., 2005, 'Entrepreneurship education research revisited: The case of higher education', Academy of Management Learning \& Education 4(1), 22-43. http://dx.doi.org/10.5465/AMLE.2005.16132536

Bosma, N., Hessels, J., Schutjens, V., Van Praag, M. \& Verheul, I., 2012, 'Entrepreneurship and role models', Journal of Economic Psychology 33(2), 410-424. http://dx.doi.org/10.1016/j.joep.2011.03.004

Carr, J.C. \& Sequeira, J.M., 2007, 'Prior family business exposure as intergenerational influence and entrepreneurial intent: A theory of planned behavior approach' Journal of Business Research 60(10), 1090-1098. http://dx.doi.org/10.1016/j. jbusres.2006.12.016

Chang, E.P.C., Memili, E., Chrisman, J.J., Kellermanns, F.W. \& Chua, J.H., 2009, 'Family social capital, venture preparedness, and start-up decisions: A study of Hispanic entrepreneurs in New England', Family Business Review 22(3), 279-292. http://dx.doi.org/10.1177/0894486509332327

Chlosta, S., Patzelt, H., Klein, S.B. \& Dormann, C., 2010, 'Parental role models and the decision to become self-employed: The moderating effect of personality', Small Business Economics 38(1), 121-138.

Collett, K. \& Gale, C., 2012, Trading up? An evaluation of JASA's Entrepreneurship Academy programme, Report, City \& Guilds Centre for Skills Development, Academy programme, Report, City \& Guilds Centre
London. http://dx.doi.org/10.1007/s11187-010-9270-y

Davidsson, P. \& Honig, B., 2003, 'The role of social and human capital among nascent entrepreneurs', Journal of Business Venturing 18(3), 301-331. http://dx.doi.org/ 10.1016/S0883-9026(02)00097-6

Dinis, A., Paço, A., Ferreira, J., Raposo, M. \& Rodrigues, R.G., 2013, 'Psychological characteristics and entrepreneurial intentions among secondary students', Education + Training 55(8/9), 763-780.

Ertuna, Z.I. \& Gurel, E., 2011, 'The moderating role of higher education', Education + Training 53(5), 387-402. http://dx.doi.org/10.1108/00400911111147703

Fatoki, O.O. \& Chindoga, L., 2012, 'Triggers and barriers to latent entrepreneurship in high schools in South Africa', Journal of Social Sciences 31(3), 307-318.

Fayolle, A., 2013, 'Personal views on the future of entrepreneurship education', Entrepreneurship \& Regional Development 25(7-8), 692-701. http://dx.doi.org Entrepreneurship \& Regional Deve
/10.1080/08985626.2013.821318

Fayolle, A. \& Liñán, F., 2014, 'The future of research on entrepreneurial intentions', Journal of Business Research 67(5), 663-666. http://dx.doi.org/10.1016/j. jbusres.2013.11.024

Ferreira, J.J., Raposo, M.L., Rodrigues, R.G., Dinis, A. \& Paço, A., 2012, 'A model of entrepreneurial intention: An application of the psychological and behaviora approaches', Journal of Small Business and Enterprise Development 19(3) 424-440. http://dx.doi.org/10.1108/14626001211250144

Gürol, Y. \& Atsan, N., 2006, 'Entrepreneurial characteristics amongst university students: Some insights for entrepreneurship education and training in Turkey' Education+Training 48(1),25-38.http://dx.doi.org/10.1108/00400910610645716

Henry, C., Hill, F. \& Leitch, C., 2005, 'Entrepreneurship education and training: Can entrepreneurship be taught? Part II', Education + Training 47(3), 158-169. http://dx.doi.org/10.1108/00400910510592211

Herman, J.L., Stevens, M.J., Bird, A., Mendenhall, M. \& Oddou, G., 2010, 'The tolerance for ambiguity scale: Towards a more refined measure for international management research', International Journal of Intercultural Relations 34(1), 58-65. http://dx.doi.org/10.1016/j.ijintrel.2009.09.004

Herrington, M., Kew, J. \& Kew, P., 2015, 2014 GEM South African Report. South Africa: The crossroads - A goldmine or a time bomb? Report, Global Entrepreneurship Monitor, Cape Town, viewed 11 May 2015, from http://gemconsortium.org/report

ILO, 2015, Global employment trends for youth 2015, Scaling up investments in decent jobs for youth, Report, International Labour Office, Geneva, viewed 5 January 2016, from http://www.ilo.org/wcmsp5/groups/public/---dgreports/--dcomm/---publ/documents/publication/wcms_412015.pdf

Junior Achievement South Africa, n.d., Mini Enterprise Programme, Brochure, South Africa.

Kalkan, M. \& Kaygusuz, A., 2012, 'The psychology of entrepreneurship', in T. BurgerHelmchen (ed.), Entrepreneurship - Born, Made and Educated, pp. 3-26, InTech, Rijeka.

Kew, J., Herrington, M., Litovsky, Y. \& Gale, H., 2013, Generation entrepreneur? The state of global youth entrepreneurship, Report, Global Entrepreneurship Monitor and Youth Business International, Cape Town, viewed 16 October 2014, from http://gemconsortium.org/report

Koh, H.C., 1996, 'Testing hypotheses of entrepreneurial characteristics: A study of Hong Kong MBA students', Journal of Managerial Psychology 11(3), 12-25. http://dx.doi.org/10.1108/02683949610113566

Kroeck, K.G., Bullough, A.M. \& Reynolds, P.D., 2010, 'Entrepreneurship and differences in locus of control', Journal of Applied Management and Entrepreneurship 15(1), 21-49.

Krueger, N.F.J., 1993, 'The impact of prior entrepreneurial exposure on perceptions of new venture feasibility and desirability', Entrepreneurship Theory \& Practice 18(1), 5-21.

Krueger, N.F.J., Reilly, M.D. \& Carsrud, A.L., 2000, 'Competing models of entrepreneuria intentions', Journal of Business Venturing 15(5), 411-432. http://dx.doi.org/ 10.1016/S0883-9026(98)00033-0

Liao, J. \& Welsch, H., 2005, 'Roles of social capital in venture creation: Key dimensions and research implications', Journal of Small Business Management 43(4), 345-362. http://dx.doi.org/10.1111/j.1540-627X.2005.00141.x

Liñán, F. \& Fayolle, A., 2015, 'A systematic literature review on entrepreneurial intentions: Citation, thematic analyses, and research agenda', International Entrepreneurship and Management Journal 11(4), 907-933. http://dx.doi.org/ 10.1007/s11365-015-0356-5 
Louden, D.M., 1978, 'Internal versus external control in Asian and West Indian adolescents in Britain', Journal of Adolescence 1(3), 283-296. http://dx.doi.org/ 10.1016/S0140-1971(78)80023-2

Mahadea, D., Ramroop, S. \& Zewotir, T., 2011, 'Assessing entrepreneurship perceptions of high school learners in Pietermaritzburg, Kwazulu-Natal', South African Journal of Economic and Management Sciences 14(1), 66-79.

Marques, C.S., Ferreira, J.J., Gomes, D.N. \& Rodrigues, R.G., 2012, 'Entrepreneurship education: How psychological, demographic and behavioural factors predict the entrepreneurial intention', Education + Training 54(8/9), 657-672.

Martínez, A.C., Levie, J., Kelley, D.J., Saemundsson, R.J. \& Schøtt, T., 2010, Globa Entrepreneurship Monitor Special Report: A global perspective on entrepreneurship education and training, Report, Global Entrepreneurship Monitor, Cape Town viewed 17 May 2014, from http://gemconsortium.org/report

Matsumoto, M., Hengge, M. \& Islam, I., 2012, Tackling the youth employment crisis: A macroeconomic perspective, working paper no. 124, International Labour Office Geneva, viewed 7 December 2012, from http://www.ilo.org/wcmsp5/groups/ public/---ed_emp/---emp_policy/documents/publication/wcms_190864.pdf

Mwasalwiba, E.S., 2010, 'Entrepreneurship education: A review of its objectives, teaching methods, and impact indicators', Education + Training 52(1), 20-47. http://dx.doi.org/10.1108/00400911011017663

Nauta, M.M. \& Kokaly, M.L., 2001, 'Assessing role model influences on students' academic and vocational decisions', Journal of Career Assessment 9(1), 81-99. http://dx.doi.org/10.1177/106907270100900106

Neck, H.M. \& Greene, P.G., 2011, 'Entrepreneurship education: Known worlds and new frontiers', Journal of Small Business Management 49(1), 55-70. http://dx.doi org/10.1111/j.1540-627X.2010.00314.X

Oosterbeek, H., Van Praag, M. \& ljsselstein, A., 2010, 'The impact of entrepreneurship education on entrepreneurship skills and motivation', European Economic Review 54(3), 442-454. http://dx.doi.org/10.1016/j.euroecorev.2009.08.002

Paço, A., Ferreira, J., Raposo, M., Rodrigues, R. \& Dinis, A., 2011, 'Behaviours and entrepreneurial intention: Empirical findings about secondary students', Journal of International Entrepreneurship 9(1), 20-38. http://dx.doi.org/10.1007/s10843of Internationa

Peng, C.Y.J., Lee, K.L. \& Ingersoll, G.M., 2002, 'An introduction to logistic regression analysis and reporting', The Journal of Educational Research 96(1), 3-14. http://dx.doi.org/10.1080/00220670209598786

Peterman, N.E. \& Kennedy, J., 2003, 'Enterprise education: Influencing students' perceptions of entrepreneurship', Entrepreneurship Theory \& Practice 28(2) 129-144. http://dx.doi.org/10.1046/j.1540-6520.2003.00035.x

Quan, X., 2012, 'Prior experience, social network, and levels of entrepreneurial intentions', Management Research Review 35(10), 945-957. http://dx.doi.org/ 10.1108/01409171211272679

Raposo, M. \& Paço, A., 2011, 'Entrepreneurship education: Relationship between education and entrepreneurial activity', Psicothema 23(3), 453-457.

Rauch, A. \& Frese, M., 2007, 'Let's put the person back into entrepreneurship research: A meta-analysis on the relationship between business owners' personality traits, business creation, and success', European Journal of Work and Organizational Psychology 16(4), 353-385. http://dx.doi.org/10.1080/ 13594320701595438
Rideout, E.C. \& Gray, D.O., 2013, 'Does entrepreneurship education really work? A review and methodological critique of the empirical literature on the effects of university-based entrepreneurship education', Journal of Small Business Management 51(3), 329-351. http://dx.doi.org/10.1111/jsbm.12021

Rodrigues, R.G., Dinis, A., Paço, A., Ferreira, J. \& Raposo, M., 2012, 'The effect of an entrepreneurial training programme on entrepreneurial traits and intention of secondary students', in T. Burger-Helmchen (ed.), Entrepreneurship - Born, Made and Educated, pp. 77-92, InTech, Rijeka.

Sánchez, J.C., 2013, 'The impact of an entrepreneurship education program on entrepreneurial competencies and intention', Journal of Small Business Management 51(3), 447-465. http://dx.doi.org/10.1111/jsbm.12025

Scarpetta, S., Sonnet, A. \& Manfredi, T., 2010, Rising youth unemployment during the crisis, Working paper no. 106, OECD, Paris, viewed 11 August 2013, from http:// zunia.org/sites/default/files/media/node-files/yo/193707_youthunemploymnt 1282469690.pdf

Shapero, A. \& Sokol, L., 1982, 'The social dimensions of entrepreneurship', in C. A. Kent, D. L. Sexton \& K. H. Vesper (eds.), Encyclopedia of entrepreneurship, pp. 72-90, Prentice-Hall, Englewood Cliffs, NJ.

Steenekamp, A.G., Van der Merwe, S.P. \& Athayde, R., 2011, 'An investigation into youth entrepreneurship in selected South African secondary schools: An exploratory study', Southern African Business Review 15(3), 46-75.

Steers, R.M. \& Braunstein, D.N., 1976, 'A behaviorally-based measure of manifest needs in work settings', Journal of Vocational Behavior 9(2), 251-266. http://dx. doi.org/10.1016/0001-8791(76)90083-X

Støren, L.A., 2014, 'Entrepreneurship in higher education: Impacts on graduates' entrepreneurial intentions, activity and learning outcome', Education + Training 56(8/9), 795-813.

Tas, A., Citci, U.S. \& Cesteneci, Y., 2012, 'The role of immigration as a social network on shaping entrepreneurship tendency: A research on Balkan immigrant entrepreneurs in Turkey', Canadian Social Science 8(4), 67-79.

Turker, D. \& Sonmez Selcuk, S., 2009, 'Which factors affect entrepreneurial intention of university students?' Journal of European Industrial Training 33(2), 142-159. http://dx.doi.org/10.1108/03090590910939049

Urban, B., 2006, 'Entrepreneurship education and entrepreneurial intentions: A prospect for higher education?' Education as Change 10(1), 85-103. http://dx.doi. org/10.1080/16823200609487131

Zeffane, R., 2013, 'Need for achievement, personality and entrepreneurial potential: A study of young adults in the United Arab Emirates', Journal of Enterprising Culture 21(1), 75-105. http://dx.doi.org/10.1142/S0218495813500040

Zhang, Y., Duysters, G. \& Cloodt, M., 2014, 'The role of entrepreneurship education as a predictor of university students' entrepreneurial intention', Internationa Entrepreneurship and Management Journal 10(3), 623-641. http://dx.doi. org/10.1007/s11365-012-0246-z

Zhao, H., Seibert, S.E. \& Lumpkin, G.T., 2010, 'The relationship of personality to entrepreneurial intentions and performance: A meta-analytic review', Journal of Management 36(2), 381-404. http://dx.doi.org/10.1177/0149206309335187 